\title{
THE DEATH OF AESTHETICS IN ARCHITECTURAL EDUCATION? POSSIBILITIES FOR CONTEMPORARY PEDAGOGY
}

Renata Jadrešin Milić

Catherine Mitchell

School of Architecture, Unitec Institute of Technology

rjadresinmilic@unitec.ac.nz

cmitchell@unitec.ac.nz

\section{A B S T R A C T}

The importance of aesthetics within architecture has a long history. Although evidence suggests that the term was not brought into architectural writing until $1735^{1}$, the place of aesthetics can be identified across architectural theory and philosophy since the time of Vitruvius. Developing an aesthetic sensibility was seen as crucial for an architect and the study of architecture was understood through the three Vitruvian lenses (utlitas, firmitas, venustas) one of which, venustas, is directly associated with aesthetics. This paper responds to the current and ongoing discussions between architects, architectural educators and architectural students on the role of aesthetics in architectural education and professional practice today. It was initially inspired by questions raised at the 2017 and 2018 annual conferences of the Society of Architectural Historians (SAH 2017 and 2018) about the role of architectural history in architectural design and practice today, and in line with this, questions about place of aesthetics in architectural education. This paper considers the place of aesthetics in architectural education and provides a detailed overview of the key pedagogical interventions undertaken in one architectural studies programme which might serve as a guide for educators interested in maintaining the place of aesthetics in contemporary architectural education. It suggests that aesthetics can continue to play a key role in the architectural curriculum whilst a focus on design problem-solving and achieving the contemporary educational requirements of accreditation is maintained. 


\section{INTRODUCTION}

At the most recent conference of the Association of Architectural Educators "Learning Through Practice" an international body of researchers and practitioner-teachers in architectural schools across the world discussed two critical questions: What is architectural education today? And, how is it connected with practice? The need for re-articulation of design as problemsolving in the education of architects was recognised and the importance of problem-solving was further connected with the present-day criteria for the ranking of the top five skills necessary for future employment in the UK based on an analysis by Bakshi and colleagues. ${ }^{3}$ These criteria are: judgment and decision-making, fluency of ideas, active learning, learning strategies and originality. In the same list "design as aesthetics" was placed in the bottom third of required skills with it being ranked number 68 out of $100 .{ }^{4}$ This suggests that aesthetics in architectural education is now, as indicated by this key domain, understood as being of circumscribed value. This paper asks: Will the demands, pressures and priorities of higher education and the profession create future practitioners with limited grounding in aesthetics based on its deprioritisation in contemporary architectural education? Many of us involved in the education of architects regularly discuss the importance of aesthetics and this is borne out in a variety of fora. For instance, the introductory sentence of the initial Concept of the Congress ICA 2019 guide recognizes aesthetics as an important philosophical, theoretical and even scientific discipline that aims at interpreting the complexity of phenomena in our world. ${ }^{5}$ However, in reality, due to the requirements to map our current course descriptors to the updated performance criteria for accreditation in architectural schools, it may be the case that sufficient curriculum space is no longer provided for aesthetics. It may be that in fact, we are facing "the death of aesthetics in architectural education". Recognition of these kinds of concerns confronting architectural educators may provide a call to action and demand from teachers creative approaches to maintain the place of aesthetics within architectural curricula. Informed by a growing body of research on the topic of professionalism that has explored the future skills of employment in architecture, this paper through the presentation of a case study advocates for the role of aesthetics in architectural education. It identifies the pedagogical value of weaving together the teaching of aesthetics with design problem-solving, ultimately with a view to strengthening professional practice. Before introducing the case study in more detail, it is worthwhile to ground our use of the term aesthetics in this paper. Although the concept is understood in diverse ways in architectural theory, it can be described in basic terms as the analysis of judgements and the objects to which they are applied. ${ }^{6}$ The 
word itself is derived from the Greek word for "feeling" which means that the discipline of aesthetics is more than just the study of beauty; it is a study of that which appeals to our senses, most often in connection with the classification, analysis, appreciation, and understanding of art. $^{7}$ As mentioned above, it is also recognised as a branch of philosophy or/and an academic discipline in a broad sense. $^{8}$

\section{THE CASE STUDY}

The case presented showcases an alternative teaching approach introduced in the School of Architecture, Unitec Institute of Technology, Auckland, New Zealand. The evidence comes from teaching the Critical Studies 1, Architectural History (CS1) course developed over three academic years, from 2016 to 2018. In contrast to the once dominant transmission approach to teaching in architectural education, ${ }^{9}$ we attempt in this critical studies course to avoid communicating large amounts of basic descriptive facts; instead, learning is based on interpretation, on the sharing of personal reactions, on setting up challenging comparisons and provoking discussion between students. While doing assigned activities, the students discover the work of significant modern architects and architectural practices and the influence of historical examples on the architect's current work. This is intended to deepen the students' understanding of the content by extending their interest and curiosity, developing critical thinking about the history of architecture, and helping them establish their own connections within our discipline. Our approach is focused on meeting the demands for previously listed future skills for employment (judgment and decision-making, fluency of ideas, active learning, learning strategies and originality), to satisfy the accreditation requirements with their focus on design problem-solving and to develop students' understanding of "design as aesthetics" by promoting interest in, and knowledge of, aesthetics values.

The main aims of CS1 include:

1) To encourage students to approach knowledge as a dynamic process discoverable for oneself, rather than to see it as something that is simply provided to them.

2) To provoke students to question the world instead of just trying to know it. 
The aims were achieved through:

a) Architectural History being presented from a point of view that corresponds to present-day demands;

b) Architectural History being coordinated with Design Studio, so that history becomes involved in the dynamics of 'making' architecture;

c) Students having an active role through taking up learning strategies to encourage them to process information and to 'construct' meanings.

d) The use of new adaptive technologies to make face-to-face learning highly engaging, collaborative and team-based. Online learning and flipped learning approaches employed to expand learning opportunities.

The diagrams below guide the teaching so that the students can see the practical aspects of the theories and histories they are learning about. This approach is especially focused on enabling students to identify how historical knowledge can be engaged with to liberate innovation in problem-solving and, at the same time, is intended to draw their attention to aesthetic considerations (in all these ways architectural history presented as the basis from which modern architecture can be learnt):

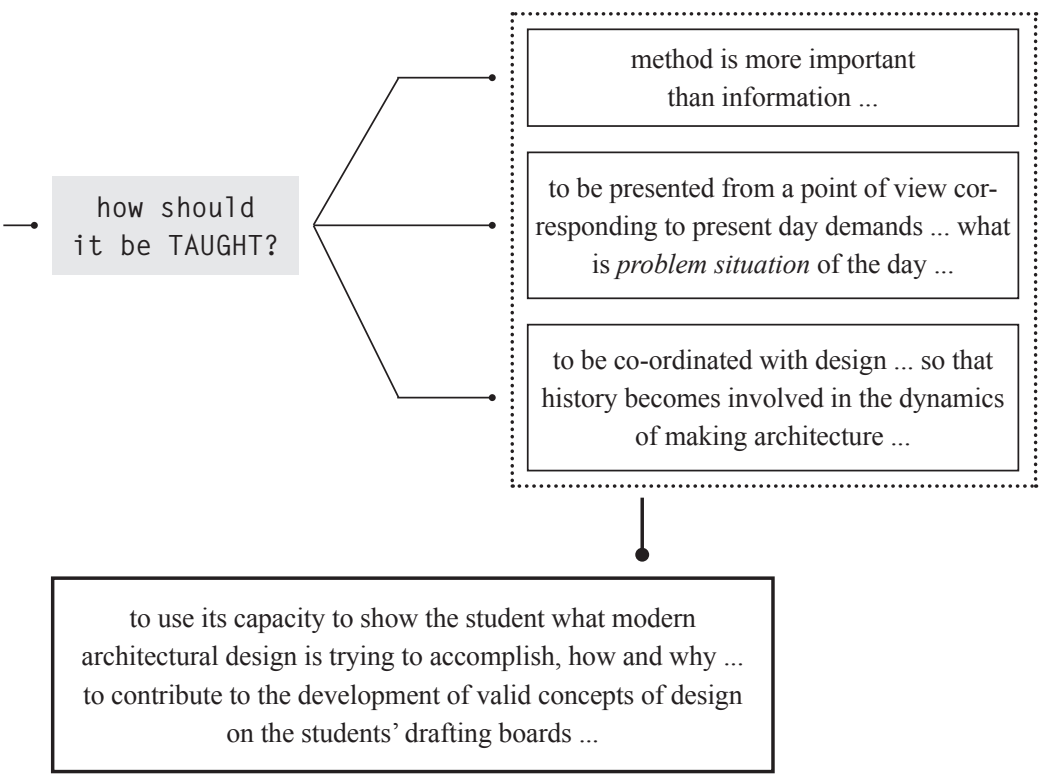


The diagram below presents the framework for CS1 course development for effective learning:

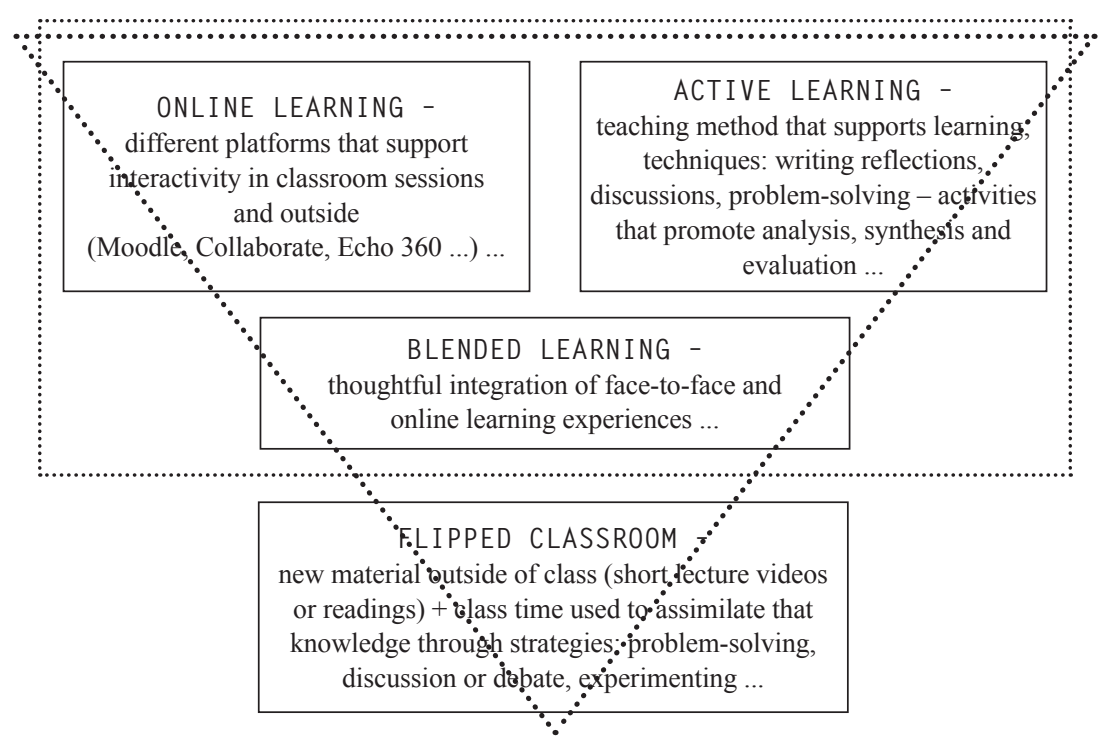

Diagram 2. The framework for the teaching provision in CS 1 course (Authors).

\section{Critical Studies 1 (Architectural History)}

The Critical Studies strand in the Bachelor of Architectural Studies (BAS) at Unitec consists of five courses, with clear and strong connections. Critical Studies 1 (Level 5) is seen as important component of the programme in providing students with the understandings and skills to manage transition between high school and university. The course focuses on scaffolding students into the BAS, discipline knowledge, and the learning and teaching approaches that span the programme. The course always has a large cohort of students (116 in 2018) and is taught through two 2-hour classes per week + one 1-hour PASS (Peer-led) class per week.

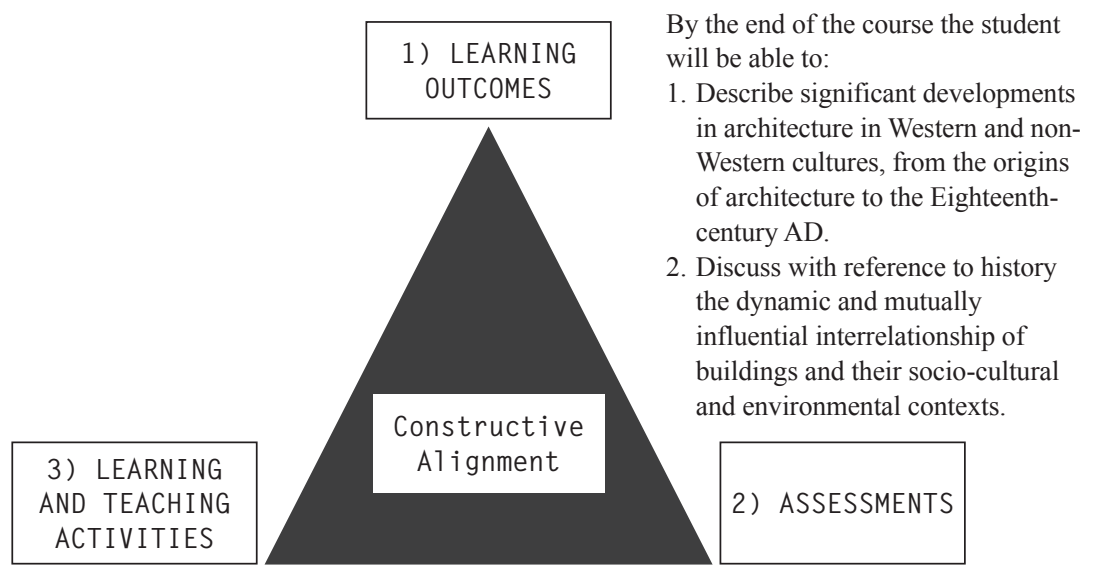




\begin{tabular}{|l|c|c|l|}
\hline \multicolumn{1}{|c|}{ ASSESSMENT TYPE } & $\begin{array}{c}\% \text { OF } \\
\text { COURSE }\end{array}$ & $\begin{array}{c}\text { WEEK IT } \\
\text { OCCURS }\end{array}$ & $\begin{array}{c}\text { FEEDBACK } \\
\text { GI VEN }\end{array}$ \\
\hline $\begin{array}{l}\text { Major Project - study of selected building - } \\
\text { Timeline } \\
\text { (Crit 1 - verbal presentation) (LO2) }\end{array}$ & $5 \%$ & 4 & $\begin{array}{l}\text { Yes - Group and } \\
\text { individual feedback. }\end{array}$ \\
\hline $\begin{array}{l}\text { Major Project - study of selected building - } \\
\text { Essay } \\
\text { (Crit 2 - verbal presentation) (LO2) }\end{array}$ & $20 \%$ & 7 & $\begin{array}{l}\text { Yes - Group and } \\
\text { individual feedback. }\end{array}$ \\
\hline $\begin{array}{l}\text { Major Project - study of selected building - } \\
\text { Drawing } \\
\text { (Crit 3 - verbal presentation) (LO1, LO2) }\end{array}$ & $25 \%$ & 11 & $\begin{array}{l}\text { Yes - Group and } \\
\text { individual feedback. }\end{array}$ \\
\hline $\begin{array}{l}\text { Buildings and terminology Identification Test } \\
\text { (LO1) }\end{array}$ & $10 \%$ & 6 & $\begin{array}{l}\text { Yes - Group } \\
\text { feedback only. }\end{array}$ \\
\hline Exam (LO1) & $40 \%$ & 15 & No feedback. \\
\hline
\end{tabular}

\section{LEARNING AND TEACHING ACTIVITIES.}

\section{MEANS AND METHODS OF THE CURRICULUM}

Preparation of content for online learning and flipped learning have proved to be positive for extending learning opportunities. Employing these learning approaches provided the means to more strongly connect to, and (possibly in future) integrate with, Design Studio. Moreover, the resources were prepared and organised to develop students thinking and learning with reference to the three Vitruvian lenses one of which, venustas, is directly associated with aesthetics. In this way, "design as aesthetics", something that has always been seen as crucial for architects, remains highly present. Design Studio "crit type questions' are prepared for Pre-class activities and applied to historical buildings in this case. Similarly, Post-class activities are designed for students so that they can analyse the most recent architectural projects as solutions to different architectural problems, previously observed in historical buildings, for example: mass, space, threshold, aperture, circulation, materials, building techniques, "corner" problem and connections between the old and the new.

\subsection{Learning by doing, practical tasks and knowledge application.}

The following table provides an overview of the design and facilitation of CS1 with reference to key teaching and learning literature. 


\begin{tabular}{|c|c|c|c|}
\hline & & & DESIGN \\
\hline & $\begin{array}{l}\text { ENGAGING STUDENTS IN THE } \\
\text { LEARNING PROCESS }\end{array}$ & $\begin{array}{l}\text { CLASS } \\
\text { TIME OR } \\
\text { INDEPENDENT } \\
\text { TIME? }\end{array}$ & FREQUENCY \\
\hline & $\begin{array}{l}\text { Pre-class activities - online experience; } \\
\text { carefully guided and structured for students } \\
\text { 'to do something'. } \\
\text { For example: } \\
\text { "The focus of this class is to explore } \\
\text { Byzantine architecture. As you watch the } \\
\text { following movie on the gorgeous Hagia } \\
\text { Sophia in Istanbul, and its breath-taking } \\
\text { dome consider these points: ..., or: Jot } \\
\text { down ... We will discuss these at the start } \\
\text { of our lecture. }\end{array}$ & $\begin{array}{l}\text { Independent, at } \\
\text { home }\end{array}$ & $\begin{array}{l}\text { Every week, } \\
\text { every session }\end{array}$ \\
\hline 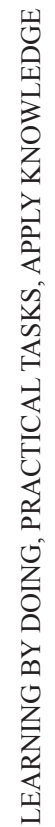 & $\begin{array}{l}\text { During class activities }- \text { face to face; } \\
\text { The students usually bring their notes from } \\
\text { the video watched for homework and share } \\
\text { responses. After this, we start the lecture and } \\
\text { seek to clarify any questions that remain. }\end{array}$ & $\begin{array}{l}\text { Class time, face } \\
\text { to face + group } \\
\text { discussions }\end{array}$ & $\begin{array}{l}\text { Every week, } \\
\text { every session }\end{array}$ \\
\hline
\end{tabular}




\begin{tabular}{|c|c|c|}
\hline & & FACILITATION \\
\hline $\begin{array}{l}\text { RATIONALE FOR THE CHOSEN } \\
\text { ACTIVITY } \\
\text { - Why this activity? } \\
\text { - How does this activity } \\
\text { assist students to meet } \\
\text { the learning outcomes? } \\
\text { - How does this activity } \\
\text { help students to cope } \\
\text { with assessment demands/ } \\
\text { requirements? }\end{array}$ & $\begin{array}{l}\text { THEORET ICAL } \\
\text { FRAMEWORK }\end{array}$ & $\begin{array}{l}\text { HOW THE LECTURER } \\
\text { SUPPORTS STUDENT } \\
\text { LEARNING }\end{array}$ \\
\hline $\begin{array}{l}\text { Students are aware of the course } \\
\text { expectations; they are clearly } \\
\text { guided. The Course Info document - } \\
\text { Important Explanations for Students, } \\
\text { is prepared with clear instructions for } \\
\text { ALL activities in the curriculum. } \\
\text { The questions prepared for pre-class } \\
\text { activities are linked to the assessment } \\
\text { events - especially important for } \\
\text { the exam (LO1); but also, this give } \\
\text { the students exposure to the types } \\
\text { of questions which flow through } \\
\text { Critical Studies strand overall (LO2). }\end{array}$ & $\begin{array}{l}\text { Cope and Kalantzis, 2015: } \\
\text { Category - Experiencing } \\
\text { the new. } \\
\text { Bloom's Taxonomy } \\
\text { levels: Knowledge; } \\
\text { Comprehension level; } \\
\text { Application; Analysis. } \\
\text { (Bloom, 1956). } \\
\text { (Brookfield, 2011) } \\
\text { (Van Sickle, 2016) } \\
\text { (Brown, 2012) } \\
\text { See Figure 1. }\end{array}$ & $\begin{array}{l}\text { Firstly, students are } \\
\text { guided to carefully read } \\
\text { and understand the } \\
\text { prepared questions. } \\
\text { Secondly, during PASS } \\
\text { (Peer Assisted Study } \\
\text { Sessions) classes we } \\
\text { check their answers } \\
\text { and clarify questions or } \\
\text { misunderstandings. We } \\
\text { try to create a supportive } \\
\text { atmosphere so that } \\
\text { students are not afraid to } \\
\text { share their opinions or to } \\
\text { make mistakes. }\end{array}$ \\
\hline $\begin{array}{l}\text { This is directly connected with the } \\
\text { LO1 primarily (and partly with } \\
\text { LO2), and leads the students towards } \\
\text { the examination; by using active } \\
\text { learning and not through memorising } \\
\text { facts only. } \\
\text { In addition, all sessions have clearly } \\
\text { named lecture topics so that the } \\
\text { students can follow where we are at } \\
\text { any moment. For example: } \\
\text { Lecture } \\
\text { Topic 1: How did the environment } \\
\text { and landscape influence architecture } \\
\text { in the old Egypt? } \\
\text { Topic 2: Materials, building } \\
\text { techniques, and constructional } \\
\text { systems in Egyptian architecture } \\
\text { Topic 3: Architectural programs in } \\
\text { Egyptian Architecture: Tombs } \\
\text { Topic 4: Architectural programs in } \\
\text { Egyptian Architecture: Temples } \\
\text { Topic 5: Aaesthetic characteristics of } \\
\text { Egyptian architecture }\end{array}$ & $\begin{array}{l}\text { Social learning theory, } \\
\text { social constructivism: } \\
\text { Discussion, debate, } \\
\text { opportunities to explore } \\
\text { diverse points of view. } \\
\text { (Richardson \& Swan, } \\
2003 \text { ) } \\
\text { (Abeysekera and Dawson, } \\
\text { 2015) } \\
\text { See Figure } 2 \text {. }\end{array}$ & $\begin{array}{l}\text { While the students } \\
\text { discuss the activities, the } \\
\text { lecturer goes around and } \\
\text { contributes to the different } \\
\text { conversations/ to answer } \\
\text { questions to extend } \\
\text { understandings. The } \\
\text { lecturer tries to encourage } \\
\text { positive interactions } \\
\text { between students. }\end{array}$ \\
\hline
\end{tabular}




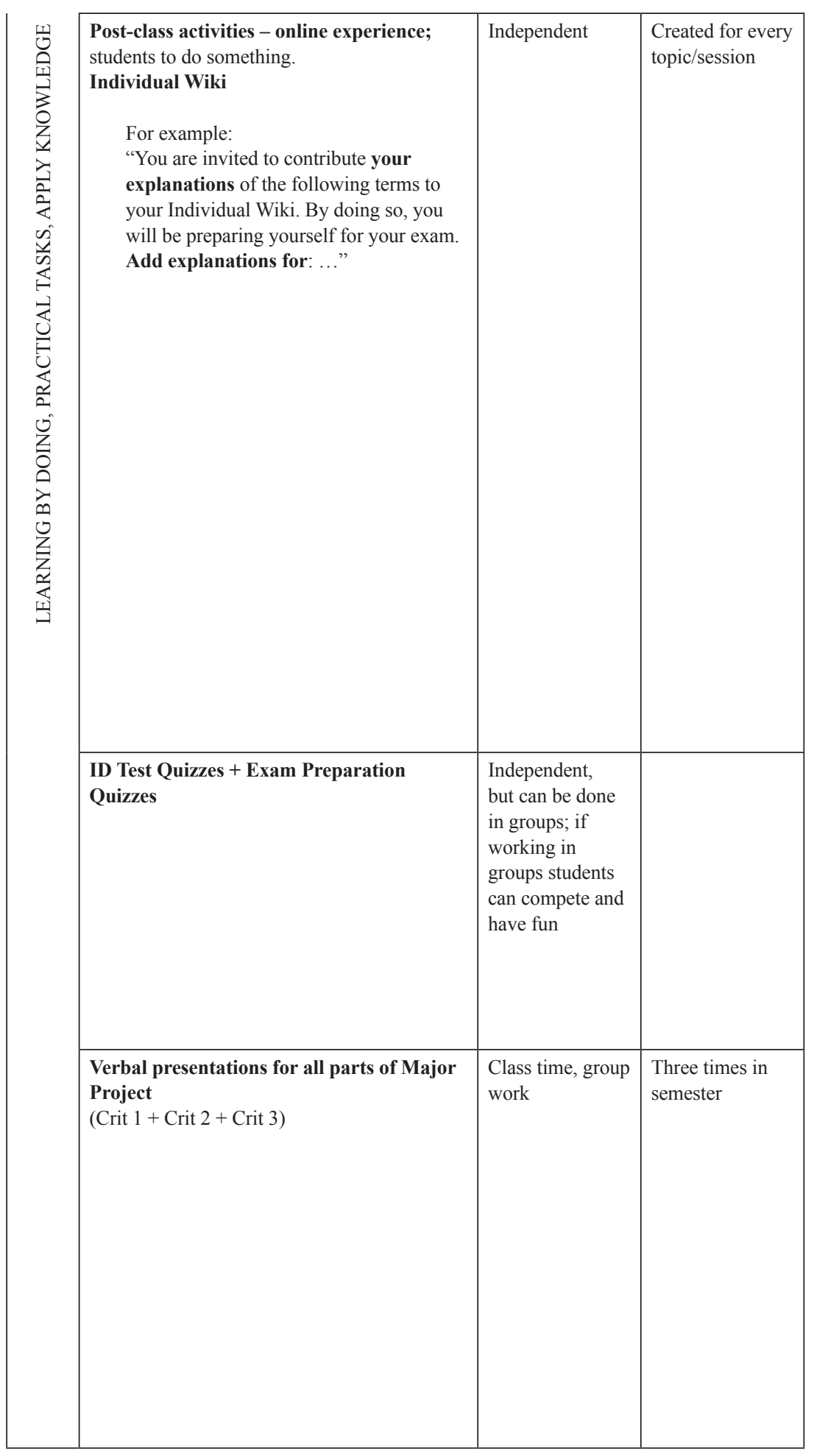




\begin{tabular}{|c|c|c|}
\hline $\begin{array}{l}\text { This activity is colour coded } \\
\text { (signalling principle): } \\
\text { Red text - preparation for the } \\
\text { exam: The students are invited to } \\
\text { contribute their explanations of } \\
\text { different architectural terms - Q2 at } \\
\text { the exam + architectural terminology } \\
\text { necessary for Design Studio and for } \\
\text { architectural practice. Each week, } \\
\text { the students are asked to find three } \\
\text { or more architectural terms listed } \\
\text { relevant to the lecture topic. These } \\
\text { terms are always carefully selected } \\
\text { and important for understanding the } \\
\text { particular topic we are talking about } \\
\text { in a particular class. (LO1) } \\
\text { From the lecturer's observation of } \\
\text { this work, the students make obvious } \\
\text { progress in terms of developing their } \\
\text { use of architectural terminology } \\
\text { generally; in thinking about what has } \\
\text { always been part of bringing design } \\
\text { decisions in architecture; of how to } \\
\text { present their findings. This work } \\
\text { is also undertaken with a view to } \\
\text { helping them develop the language } \\
\text { to explain their own design work - } \\
\text { architectural work. (LO2) }\end{array}$ & $\begin{array}{l}\text { Bloom's Taxonomy } \\
\text { levels: Knowledge; } \\
\text { Comprehension level. } \\
\text { (Bloom, 1956). } \\
\text { Cognitivism: Activating } \\
\text { prior learning; Use } \\
\text { analogies and metaphors } \\
\text { to explain concepts; Note- } \\
\text { taking, mnemonics. } \\
\text { (Brookfield, 2011) } \\
\text { (Westermann, 2014) } \\
\text { See Figure 3. }\end{array}$ & $\begin{array}{l}\text { We check this together } \\
\text { during PASS classes. } \\
\text { Both the Wiki and Q\&A } \\
\text { forum (see in the next } \\
\text { section) are tools used } \\
\text { to enable students to } \\
\text { get timely feedback. } \\
\text { Also, student-student } \\
\text { and student-teacher } \\
\text { interactions are facilitated } \\
\text { in this process. Inclusion } \\
\text { of these tools means } \\
\text { the course is highly } \\
\text { accessible from a variety } \\
\text { of platforms and devices } \\
\text { (provided students have } \\
\text { access to the internet). }\end{array}$ \\
\hline $\begin{array}{l}\text { All quizzes are practice quizzes and } \\
\text { can be repeated as many times as } \\
\text { the students want. By doing so they } \\
\text { check their knowledge, learn from } \\
\text { previous mistakes, and they are } \\
\text { prepared for the ID test and exam } \\
\text { question Q1, on time. (LO1) }\end{array}$ & $\begin{array}{l}\text { Bloom's Taxonomy } \\
\text { levels: Knowledge. } \\
\text { (Bloom, 1956). } \\
\text { (Westermann, 2014) } \\
\text { (Spector, 2016) }\end{array}$ & $\begin{array}{l}\text { The students are } \\
\text { encouraged to start } \\
\text { practicing early and } \\
\text { together, to foster } \\
\text { interaction between them. } \\
\text { The lecturer follows/ } \\
\text { checks their success } \\
\text { online, and draws their } \\
\text { attention to the most } \\
\text { common mistakes in } \\
\text { class. }\end{array}$ \\
\hline $\begin{array}{l}\text { Verbal presentation of the students } \\
\text { Timelines, Essays and Drawings - } \\
\text { considered to be group sharing and } \\
\text { discussion about students' findings; } \\
\text { the students have been engaged and } \\
\text { they participate by listening to each } \\
\text { other with care; } \\
\text { The students apply learning gained in } \\
\text { previous weeks to each new task; } \\
\text { The students use the knowledge } \\
\text { previously gained in a creative way } \\
\text { (LO2). }\end{array}$ & $\begin{array}{l}\text { Social learning theory, } \\
\text { social constructivism: } \\
\text { Discussion, debate, } \\
\text { opportunities to explore } \\
\text { diverse points of view. } \\
\text { (Richardson \& Swan, } \\
2003 \text { ) }\end{array}$ & $\begin{array}{l}\text { The lecturer facilitates this } \\
\text { work and tries to create } \\
\text { a supportive atmosphere } \\
\text { and environment. } \\
\text { The lecturer gives an } \\
\text { immediate feedback, } \\
\text { important for the learning } \\
\text { overall. Additional } \\
\text { questions are asked } \\
\text { - about the students' } \\
\text { experience while they } \\
\text { worked on assignment, } \\
\text { what was good/not good; } \\
\text { what was hard/easy; what } \\
\text { could be done differently. }\end{array}$ \\
\hline
\end{tabular}


Prepare for Class

The focus of this class is to explore Byzantine architecture. As you watch the following movie on the gorgeous Hagla Sophla in Istanbul, and its $\quad \square$ CONTEXT

CONTEXT

UTILTAS

- What is Iongitudinally planned space? Explain and make a sketch.

- Compare the two and explain the difference.

FIRMITAS

- What is the height of the dome? And the diameter?

- What is the height of the dome? And the diameter?
Compare the dome with the Pantheon's dome. What is

- What are pendentives

- What did support the woignt and the trust of the dome?

VENUSTAS

- Note that the the dosac?

We will discuss these at the start of our lecture.

Hagia Sophia in Istanbul

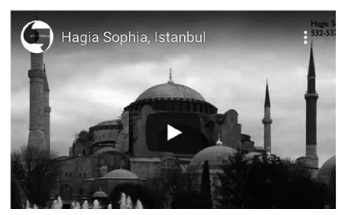

- What did Egyptians "imitate" while making those beautiful columns?
We will discuss these at the start of our lecture.

The Pyramid of Pharaoh Djoser at Saggara

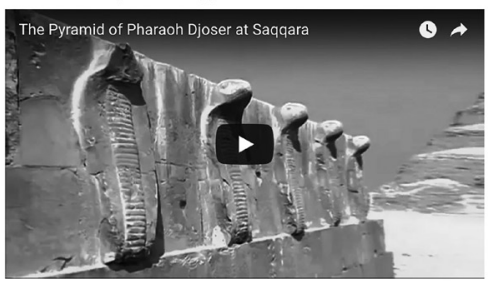

\section{During Class}

Video Discussion: Review in Groups (20 minutes)

In this session the lecturer will ask you to talk in small groups about the video and the answers to the questions that

were astod

Topic 1: How did the environment and landscape influence architeoture in the old Egypt?

Topic 2: Materials, bulding tochniques, and Constructional systems in Egyptian architecturo

Topic 3: Architectural program in Egyptian Architecture: Tombs

Topic 4: Architectural proaram in Eavotian Architecture: Temoles

\section{Follow-up Activities}
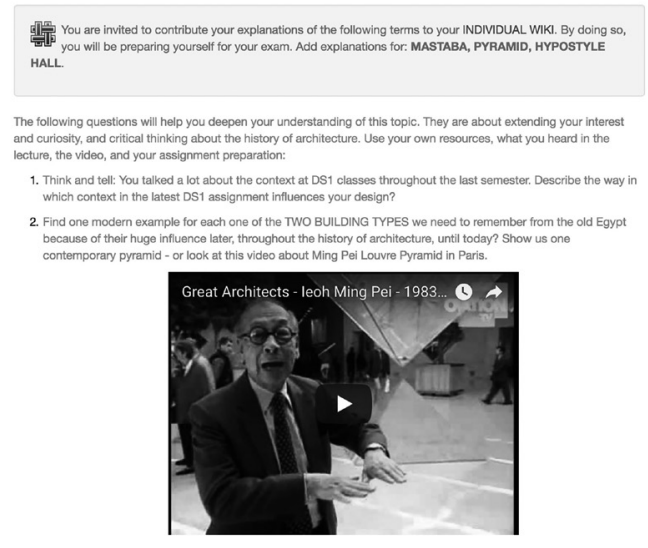

How does Ming Pei compare his Louvre Pyramid with Egyptians?
Fig. 1

Pre-class activities - online experience. Moodle page with one session example.

Fig. 2.

During class activities - face to face. Moodle page with one session example.

\section{Fig. 2.}

Post-class activities - online experience face to face. Moodle page with one session example. 
Overall, the previous table provides an account of the ways CS1 is taught with a focus on developing student understandings of architectural history through the development of design thinking and in connection with design problem-solving processes. This is achieved while maintaining a clear focus on developing students' aesthetic sensibilities and knowledge.

\subsection{Engaging with abstract theory or concepts}

To further identify the pedagogy used in Critical Studies 1 an account of the approaches to facilitate student engagement with abstract theory and concepts that include "design as aesthetics" is provided. This is important as many students of architectural history grapple with the range of theoretical concepts and theory that form an essential part of the subject. The table below provides an overview of the ways in which we sought to address some of these challenges.

This table contributes more depth to the account of the pedagogical interventions employed in Critical Studies 1 and to enable practitioners understand the ways in which the teaching of theory, including aesthetics, can be approached to facilitate student learning. Evidence of the value of our pedagogical approach is identified within the architectural history course in terms of increased student engagement and improved academic results. The course results from 2015 to 2018 demonstrate that the number of ' $A$ ' level grades - 4\% in 2015, was raised to $16 \%$ in 2018 indicating improved learning and achievement at the higher levels. 


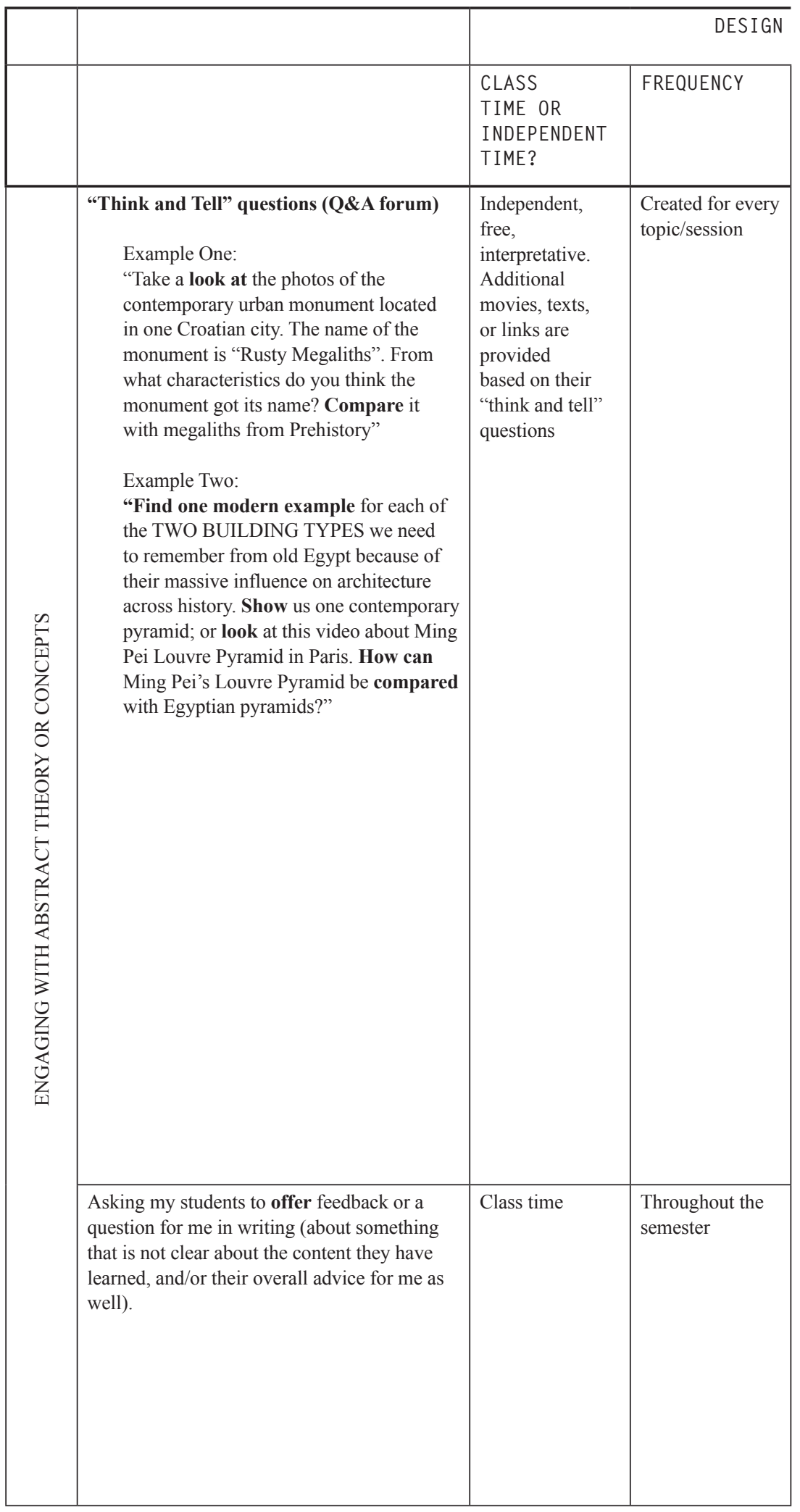




\begin{tabular}{|c|c|c|}
\hline & & FACILITATION \\
\hline $\begin{array}{l}\text { RATIONALE FOR THE CHOSEN } \\
\text { ACTIVITY }\end{array}$ & $\begin{array}{l}\text { THEORETICAL } \\
\text { FRAMEWORK }\end{array}$ & $\begin{array}{l}\text { HOW THE LECTURER } \\
\text { SUPPORTS STUDENT } \\
\text { LEARNING }\end{array}$ \\
\hline $\begin{array}{l}\text { With this task the students learn how } \\
\text { to connect theoretical principles } \\
\text { (often abstract) and architectural } \\
\text { practice with reference to the } \\
\text { history of architecture and aesthetic } \\
\text { ideas; and how to apply theoretical } \\
\text { principles in their Design Studio work } \\
\text { today. It is also important for the } \\
\text { assessment Major project - Essay. } \\
\text { (LO2) } \\
\text { This activity is colour coded as: } \\
\text { Green text. It is designed to become } \\
\text { a dynamic online discussion and a } \\
\text { shared learning resource: } \\
\text { - By doing these activities the } \\
\text { students find out about the } \\
\text { most famous modern architects, } \\
\text { architectural firms, recent } \\
\text { significant contemporary designs } \\
\text { and key architectural awards. In } \\
\text { combination, this knowledge helps } \\
\text { students understand the importance } \\
\text { of history of architecture for } \\
\text { contemporary design practice. } \\
\text { - It can also help them to think about } \\
\text { how they can establish their own } \\
\text { connections across the discipline. } \\
\text { - Answering the posed questions } \\
\text { should help students to deepen their } \\
\text { understanding of the topic, extend } \\
\text { their interest and curiosity and help } \\
\text { them develop critical thinking about } \\
\text { the history of architecture. } \\
\text { - The students are encouraged to use } \\
\text { their own resources, what they hear } \\
\text { in lectures, the videos, and all their } \\
\text { assignment preparation as building } \\
\text { blocks for a solid, useful and } \\
\text { meaningful architecture practice. }\end{array}$ & $\begin{array}{l}\text { Bloom's Taxonomy } \\
\text { levels: Knowledge; } \\
\text { Comprehension level; } \\
\text { Application; Analysis; } \\
\text { Synthesis. } \\
\text { (Bloom, 1956). } \\
\text { Constructivism: Build } \\
\text { knowledge by doing; } \\
\text { Learning from reflection; } \\
\text { Problem-based learning; } \\
\text { Experimentation. } \\
\text { (Brookfield, 2011; } \\
\text { Bransford et al., 1999). }\end{array}$ & $\begin{array}{l}\text { Primarily this approach } \\
\text { is designed to broaden } \\
\text { the students' views and } \\
\text { help them understand the } \\
\text { purpose of everything we } \\
\text { learn. } \\
\text { Further, the Q\&A } \\
\text { discussion forum allows } \\
\text { students to share their } \\
\text { research with the lecturer } \\
\text { and tutors, as well as with } \\
\text { their peers, and stimulate } \\
\text { some engaging discussion } \\
\text { around the topics given. }\end{array}$ \\
\hline $\begin{array}{l}\text { Every new class starts with a short } \\
\text { reflection about students' enquiries } \\
\text { (feedback from students often arrives } \\
\text { through e-mails, not in direct contact). } \\
\text { Between our session - whenever } \\
\text { necessary or urgent, e-mails are } \\
\text { sent to all students through Moodle } \\
\text { (especially before major assignment } \\
\text { submissions, with a reminder bullet } \\
\text { pointing of the most important } \\
\text { expectations, criteria, grading rubric } \\
\text { and similar). }\end{array}$ & $\begin{array}{l}\text { Importance of self- } \\
\text { reflection in learning } \\
\text { process (Fink, 2003) }\end{array}$ & $\begin{array}{l}\text { Lecturer to show to the } \\
\text { students that he/she values } \\
\text { their feedback and is } \\
\text { focused on contributing to } \\
\text { their learning. }\end{array}$ \\
\hline
\end{tabular}




\section{KEY CHALLENGES}

As can be identified from the discussion so far, multiple strategies were employed in Critical Studies 1 to facilitate student learning through making more explicit links between architectural history and design. However, the utilisation of these strategies and approaches was not without challenge. In brief, the most notable challenges we encountered included:

- Student resistance to engaging with activities;

- Student reluctance about working with others;

- The amount of time some activities take in class time;

- Technical problems with the e-platform.

To address the first of the two related issues of student resistance to engaging with activities and working with others we found that providing a clear overview of the expectations at the beginning of the course and identification of the value of the benefits of active learning was useful. Moreover, being consistent with structure and order of the session meant that the students became more familiar with the ways the course was structured and participated more readily. The issue relating to the amount of class time taken with activities is significant and an ongoing consideration especially with regard activity preparation. Over the three-year period of active re-development of the course we learned more about how certain activities could be made to fit within the class time though there remains as with all teaching some unpredictability in terms of how students engage and respond. The last major issue encountered involved technical matters often in relation to our course wiki, something we continue to work on with our technical colleagues at our institution.

\section{CONCLUSION}

This paper has identified the key pedagogical interventions undertaken in Critical Studies 1, a first-year architectural history course in the Bachelor of Architectural Studies at Unitec Institute of Technology in Auckland, New Zealand. In this course we moved away from traditional teaching approaches typically relied upon in architectural history and instead focused on: Content and Interaction through questions/problems: Video + questions; Interactivity (with Others) Focus: Facilitated synchronous discussion; Critical Thinking: Response to an assigned video/short text; Production: Oral summary/presentation; written essay; drawing; Reflection: Reflection on Learning. With these strategies we sought to emphasise the value and relevance of architectural history by making explicit the connections between developing an aesthetic sensibility and 
design problem-solving processes in contemporary architecture. In this way, our work represents our intent to draw together a number of different threads in the architecture curriculum where we promote design problem-solving, critical thinking and aesthetics. While development and refinement necessarily continues, it is hoped that the sharing of our practice may benefit educators who are seeking insights into how they can achieve stronger connections between architectural history, aesthetics and design studio in their own teaching. 
Alexander Gottlieb Baumgarten (1714-1762), a German philosopher, was the first to use the word "aesthetics"; see: Paul Guyer, "18 $18^{\text {th }}$ Century German Aesthetics," The Stanford Encyclopedia of Philosophy (Winter 2016 Edition), Edward N. Zalta (ed.). Available at: https://plato.stanford.edu/ archives/win2016/entries/aesthetics-18th-german/.

The fifth international conference of the Association of Architectural Educators "Learning Through Practice", 24-26 April 2019, the University of Westminster in London. Availabe at: https:// aaeconference2019.wordpress.com/.

Hasan Bakhshi, Jonathan Downing, Michael Osborne, and Philippe Schneider, The Future of Skills: Employment in 2030 (London: Pearson and Nesta, 2017).

Alan Jones, "Professionalism in Architectural Education," Debate on Architectural Education and Professionalism convened by SCHOSA (Standing Conference of the Heads of Schools of Architecture in the UK), 24 April 2019, the University of Westminster in London; data based on: Bakhshi, Osborne, and Schneider, The Future of Skills: Employment in 2030, 67-68. between History, Geography and Media, Book of Abstracts (University of Belgrade Faculty of Architecture, Belgrade, 2019), 7.

Jerry Palmer, Mo Dodson, (eds). Design and Aesthetics: A Reader (Routledge, 1996), 3-12; for main turning points in history of aesthetics see Aleš Erjavec, "The Status of Aesthetics Today," SAJ Vol. 7 (2015): 1-8. Available at: http://saj.rs/wp-content/uploads/2017/03/SAJ-2015-01-A-Erjavec. pdf.

Dabney, Townsend. The A to Z of Aesthetics (Scarecrow Press, 2010).

Townsend. The A to $Z$ of Aesthetics.

Transmission pedagogy involves teacher-centred approaches to teaching based on a view of learning as a process of acquisition of information transferred or transmitted from teachers (as experts) to students who framed as 'empty vessels' to be filled with knowledge; see: C. Greig Crysler, "Critical Pedagogy and Architectural Education," Journal of Architectural Education 48, no. 4 (1995): 208, 210; David J. Nicol and Debra Macfarlane-Dick, "Formative Assessment and Self-regulated Learning: A Model and Seven Principles of Good Feedback Practice," Studies in Higher Education 31, no. 2 (April 2006): 199-218, 200. Available at: https://doi.org/10.1080/03075070600572090. 
Abeysekera, Lakmal, and Phillip Dawson, "Motivation and Cognitive Load in the Flipped Classroom: Definition, Rationale and a Call for Research," Higher Education Research \& Development, 34 (2015), 1-14. Available at: https://doi.org/10.1080/07294360.2014.934336.

Bakhshi, Hasan, Jonathan Downing, Michael Osborne, and Philippe Schneider, The Future of Skills: Employment in 2030, London: Pearson and Nesta, 2017.

Bloom, Benjamin S. (Benjamin Samuel), Taxonomy of Educational Objectives; the Classification of Educational Goals, New York: Longmans, Green, 1956.

Bransford, John, National Research Council (U.S.). Committee on Developments in the Science of Learning., and National Research Council (U.S.). Committee on Learning Research and Educational Practice., How People Learn: Brain, Mind, Experience, and School, National Academy Press, 2000.

Brookfield, Stephen, Teaching for Critical Thinking: Tools and Techniques to Help Students Question Their Assumptions, Hoboken, NJ: Jossey-Bass, 2012.

Brooks, D. Christopher, "Space and Consequences: The Impact of Different Formal Learning Spaces on Instructor and Students Behavior," Journal of Learning Spaces, 1 (2012), 1-10.

Brown, Brené, Daring Greatly: How the Courage to Be Vulnerable Transforms the Way We Live, Love, Parent, and Lead, New York: Gotham Books, 2012.

Cope, Bill, and Mary Kalantzis, eds., A Pedagogy of Multiliteracies: Learning by Design, Houndsmills, United Kingdom, 2015.

Crysler, C. Greig, "Critical Pedagogy and Architectural Education," Journal of Architectural Education 48, no. 4 (1995), 208-17.

Guyer, Paul, "18 ${ }^{\text {th }}$ Century German Aesthetics," The Stanford Encyclopedia of Philosophy (Winter 2016 Edition), Edward N. Zalta (ed.). Available at: https://plato.stanford.edu/archives/win2016/ entries/aesthetics-18th-german/.

Fink, L. Dee, Creating Significant Learning Experiences: An Integrated Approach to Designing College Courses, San Francisco: Jossey-Bass, 2003.

Nicol, David J., and Debra Macfarlane-Dick. "Formative Assessment and Self-regulated Learning: A Model and Seven Principles of Good Feedback Practice." Studies in Higher Education 31, no. 2 (April 2006), 199-218. Available at: https://doi.org/10.1080/03075070600572090.

Palmer, Jerry, and Mo Dodson, eds., Design and Aesthetics: A Reader, New York: Routledge, 1996.

Richardson, Jennifer C., and Karen Swan, "Examininig Social Presence in Online Courses in Relation to Students' Perceived Learning and Satisfaction," Journal of Asynchronous Learning Networks, 7 (2003), 68-88.

Spector, J. Michael, Foundations of Educational Technology: Integrative Approaches and Interdisciplinary Perspectives, New York: Routledge, 2016.

Society of Architectural Historians, "Publications: Past Conferences," 2019. Available at: https:// www.sah.org/conferences-and-programs/past-conferences.

Townsend, Dabney, The A to Z of Aesthetics, Scarecrow Press, 2010.

Van Sickle, Jenna, "Discrepencies between Student Perception and Achievement of Learning Outcomes Ina Flipped Classroom," Journal of the Scholarship of Teaching and Learning, 16 (2016), 29-38. Available at: https://catalogue.library.auckland.ac.nz/primo-explore/ search?query=any,contains, discrepencies between student perception and achievement of learning outcomes in a flipped\&tab $=$ articles\&search scope $=$ Primo Central\&vid $=$ NEWUI\&offset $=0$ [accessed 18 May 2019].

Westermann, Edward B., "A Half-Flipped Classroom or an Alternative Approach? Primary Sources and Blended Learning," Educational Research Quarterly, 38 (2014), 43-57. Available at: https:// www.library.auckland.ac.nz/search/westermann \%22a half-flipped classroom or an alternative approach?\%22 [accessed 19 May 2019]. 


\section{ESTETIKA ODRŽIVOSTI: ARHITEKTURA KAPSULE U GRADU I U PRIRODI Peter Šenk}

Arhitektura najmanjih mesta za stanovanje je u poslednje vreme izuzetno popularna tema. Kada su najmanja mesta za stanovanje kompaktna, dobro opremljena, povezana na mrežu, strukturno, funkcionalno i vizuelno prepoznata kao jedna stvar, privremena i pokretna ili prenosiva, mogu se označiti kao arhitektura kapsule. Budući da su po svojoj prirodi privremena, ova najmanja mesta za stanovanje, skloništa, redizajnirane kontejnerske jedinice, posebne tehnološke konstrukcije, paraziti i druge manifestacije koncepta kapsula obuhvataju logiku tehnoloških objekata s izrazitim arhitektonskim izrazom. To je, istovremeno, manifestacija pravila održivog dizajna, održive arhitekture i održivosti uopšte. U ovom kontekstu slučaj najmanjih mesta za stanovanje pokazuje svoju razliku u odnosu na druge održive arhitektonske pristupe i estetike. Podredjuje uopšteno održive pristupe sa izraženim značajem lokaliteta unutar globalnih sila, obično se oslanjajući na kontekst - lokaciju, lokalnu kulturu i karakteristike životne sredine itd. Estetski režim trenutnih, promenljivih, kontekstualnih i autonomnih arhitektonskih struktura se može posmatrati kao estetika drugosti, koja ih povezuje sa nasledjem egzistencijalnih eksperimenata modernog pokreta, novim brutalizmom, radikalnim eksperimentima 1960-ih i drugim avangardnim i neoavangardnim praksama dvadesetog veka, ali čvrsto postavljenim u kontekstu individualizovane, neodredjene, raspršene i dvosmislene savremenosti.

KLJUČNE REČI: ESTETIKA PROMENE, KAPSULE, NAJMANJA MESTA ZA STANOVANJE, MINIMALAN TRAG, DRUGOST, ESTETIKA ODRŽIVOSTI

\section{ESTETIKA I KULTUROLOŠKI ASPEKTI BAUHAUSA: \\ KA NOVOJ KONCEPCIJI}

\section{Christiane Wagner}

Ovaj članak pokriva nove mogućnosti Bauhaus pogleda na svet: stvaranje novih oblika za prikazivanje ljudskih ideala kroz fokus na estetiku i tehnologiju, u kombinaciji sa Nimajerovim (Niemeyer) uticajem na arhitekturu i dizajn. Novi stilovi i oblici nastali su kao izdanci Bauhausa, prenoseći vrednosti svake kulture kroz izgradnju kolektivne „slike“ sveta. Bauhaus današnjice izražava industriju kulture, dijalektički razmatrajući inovaciju i primenjenu umetnost kao put od modernog dizajna industrijske revolucije do „eko dizajna“. U tom smislu, Bauhaus je još uvek značajan po svojoj ulozi, povezujući umetnost, tehnologiju i industriju. Inovacija kao dinamično odredjivanje trenutka, prisutna u svim epohama, se shvata kao moćna sila za održavanje tradicije. Pored hronološkog zapisa o uticaju Bauhausa, razmatraju se i značajni Nimajerovi projekti. Na kraju su prikazane dve perspektive ,raskola“ izmedju arhitekture i tehnologije. Prva perspektiva se odnosi na ljudsku sposobnost stvaranja modela u arhitektonskoj praksi za usvajanje kao konfiguraciju prostora. Druga se odnosi na evoluciju tehnologija koje vode do toga da zamišljeno postaje stvarnost kroz vreme, kako je to opisao Hegel (1823).

KLJUČNE REČI: IZRADA PO MERI, TEHNOLOŠKI RAZVOJ, PROSTOR-VREME, NOVI OBLICI

\section{KLASIČNA ARHITEKTURA U OKVIRU KANTOVSKE ESTETIKE: IZMEĐU LIOTARA I RANSIJERA}

\section{Helen Tatla}

Potencijal koji je svojstven klasičnoj arhitekturi da predstavlja glavni arhitektonski izraz zapadne kulture budući da je grčka antika nastala zbog svog dualnog karaktera: iako izvire iz iskonskog jedinstva stvari izraženih mitom i religijom u arhaičnim vremenima, ona dobija svoj završni oblik u petom veku p. n. e., kao simbol demokratije i harmonične artikulacije sveta na osnovu filozofskog mišljenja. 
Postavljajući avangardnu umetnost u sferu kantovske uzvišenosti, Žan Fransoa Liotar (JeanFrancois Lyotard) se fokusira na nemogućnost apsolutnog odnosa razuma i percepcije ili između razmišljanja i slike, u savremenosti. On smatra da se u slučajevima kada se to dogodi radjaju politička čudovišta. On povezuje postmoderne izraze klasicizma u arhitekturi sa Frojdovim „Tumačenjem snova“" i kantovskom lepotom.

Pristup Žaka Ransijera (Jacques Ranciere) kantovstvu na osnovu estetskog razmatranja modernosti suprotan je onome koji je predložio Liotar. Umesto uzvišenog, Ransijer povezuje lepo s pukotinom izmedju razmišljanja i percepcije. U tom pogledu, fragmenti prošlosti mogu da podstaknu kreativni proces u sadašnjosti.

Cilj ovog istraživanja je da doprinese dijalogu o obnovljenom pristupu ulozi klasicizma u arhitekturi danas.

KLJUČNE REČI: KLASIČNA ARHITEKTURA, KANT, LIOTAR, MODERNOST, POLITIKA, POSTMODERNOST, RANSIJER

\section{FLUIDNO STANJE ARHITEKTURE}

\section{Bojana Jerković-Babović}

Ovaj rad se bavi promenama u kriterijumima arhitektonske estetike, transformacija statičnih u dinamične vrednosti podjednako figurativnih i nefigurativnih aspekata savremene arhitekture i njenog konteksta. Fluidno stanje arhitekture odnosi se na prepoznavanje konstantne promenljivosti koja se manifestuje u relacijama arhitekture i savremenom kultuloroškog konteksta globalizacije. Savremeni kontekst dinamizuje perceptivna iskustva svakodnevnice, uslove života i načine prostornih aproprijacija. U skladu sa tim, novi fenomeni umreženosti koji se manifestuju na informacionim, komunikacionim i prostornim nivoima transformišu grad i arhitekturu u konstantne procese tokova, kojima se njihovi elementi dematerijalizuju u nove fluidne, promenljive karakteristike. Vredosti arhitektonske estetike istovremeno se transformišu ka afirmaciji dogadjaja i efekata naspram statične formale celine, od objektivnih do intersubjektivnih estetskih prostornih iskustava.

Ovaj rad se bazira na hipotezi da savremenu arhitekturu karakteriše gubitak singularnosti objekta u odnosu sa uslovima konteksta i asimilacija karaktera pojedinačnih elemenata u fluidni karakter celine. Na taj način, arhitektonske projektantske principe karakteriše disperzija disciplinarnih granica i granica unutrašnjosti i spoljašnjosti, hibridnost i gubitak tipoloških definicija. Ovaj rad prikazuje kako dematerijalizacija arhitektonskih vrednosti transformiše savremeni arhitektonski prostor u kompleksan dinamički sistem infrastrukture, tokova, događaja i efekata.

KLJUČNE REČI: ARHITEKTONSKA ESTETIKA, ARHITEKTONSKO PROJEKTOVANJE, ESTETSKO ISKUSTVO, DINAMIČKE VREDNOSTI, FLUIDNOST, GLOBALIZACIJA

\section{KINEMATOGRAFIJA I ARHITEKTURA: MODERNA PERCEPCIJA Sônia Campaner Miguel Ferrari}

Esej Valtera Benjamina (Walter Benjamin) o bioskopu objašnjava njegove prognostičke vrednosti. Dok je pisao ovaj članak, njegova kritika kapitalističkog načina produkcije pokazala je pravac u kojem kapitalizam napreduje: ka sve većoj eksploataciji proletarijata, ali i ka svom vlastitom padu. Nas zanimaju ove prognoze koje potvrdjuju transformaciju umetnosti i njene funkcije, a koja našu pažnju usmeravaju na gubitak transcedencije i opadanja aure umetničkog dela. One u isto vreme pokazuju mogućnosti kojima se potvrđuje kontinuitet umetnosti koja ima drugačiju ulogu i dislokacija aure. Oblik umetnosti koji je pogodan za ovakvo razmišljanje je kinematografija i paralela koju je filozof povukao izmedju kinematografije i arhitekture. Namera nam je da se osvrnemo na ovu paralelu i urbane intervencije kao umetničke oblike estetske modernosti: to 
jest, kao proizvode ove modernosti koji istovremeno ukazuju na način koji nam je dat i shvaćen. Takodje ćemo se osvrnuti i na indikacije bioskopa i pozorišta kao načina da se prevazidju telesne odrednice koje nam se nameću.

KLJUČNE REČI: ARHITEKTURA, BIOSKOP (KINEMATOGRAFIJA), MODERNA UMETNOST, MODERNA PERCEPCIJA, URBANIZAM

\section{AUTORSTVO I JEZIK U KNJIGAMA SAVREMENIH ARHITEKATA}

\section{Deniz Balık Lökçe}

Ovaj rad se bavi ispitivanjem teorijskih, grafičkih i materijalnih dimenzija savremene kulture štampe u arhitekturi sa fokusom na po jedno delo iz različitih evropskih praksi. Knjiga savremenog arhitekte posmatra se kao spekulativni i diskurzivni predmet dizajna. Mišel Fuko (Michel Foucault), posebno u svojim delima, Šta je autor? (1969) i Arheologija znanja (1972), kritikuje to da se prilikom izrade opusa jednog autora alternativni i neklasifikovani žanrovi izostavljaju iz domena, a tekstovi koji se vezuju za jedno ime pripadaju sistemu homogenosti, veze i recipročnog objašnjenja. Ipak, knjiga savremenog arhitekte proširuje granice žanrova tako što je sačinjena od nekonvencionalnih materijala, poput muzičkih nota, umetničkih fotografija, slika, tehničkih i naučnih dijagrama, zvaničnih izveštaja, gradjevinskih propisa, novinskih članaka i reklama, a takođe i od kombinacije tekstova i fotografija saradnika, partnera, klijenata i korisnika, a ne samo kao produkt jednog autora. Ovaj rad se bavi tumačenjem korišcenja različitih oblika grafičke naracije i spajanja nove terminologije i žargona kao doprinosa moći jezika i diskurzivnoj formaciji.

KLJUČNE REČI: ARHITEKTONSKI MEDIJI, ARHITEKTONSKA MONOGRAFIJA, KNJIGA, FUKO, ŽANR, KULTURA ŠTAMPE, AUTOR, TEKST

\section{ARHITEKTURA KAO TEKSTUALNI FENOMEN: APROPRIJACIUSKE ARHITEKTONSKE PRAKSE ALEKSANDRA BRODSKOG Boško Drobnjak}

Tekst analizira arhitekturu nastalu aproprijacijom postojećih materijala fokusirajući se na strategije intertekstualnosti. Rad zastupa tezu da značenje arhitektonskog objekta ne proizlazi iz njega samog ili njegovih poetskih koncepata, već iz njegovih odnosa sa drugim arhitektonskim objektima, drugim umetničkim delima kao tekstovima, kulturalnim tekstovima i svakodnevnim životnim praksama. Cilj rada jeste da se pokažu različiti teorijski problemi teorije arhitekture i umetnosti koji kao mreža uodnošenih tekstova kulture okružuju arhitektonsku produkciju Aleksandra Brodskog (Alexander Brodsky). Za metod rada je karakteristično operisanje sa različitim i raznorodnim teorijskim konceptima, uzimajući odabrane studije slučaja (Votka paviljon i Rotunda) arhitekture Brodskog u okviru koje je rad koncipiran kao interdisciplinarna studija.

KLJUČNE REČI: ALEKSANDAR BRODSKI, APROPRIJACIJA, SVET UMETNOSTI, EKSPERIMENTALNA ARHITEKTURA, READY-MADE, TEKST

\section{PITER AJZENMAN I MOGUĆNOST ESTETSKOG FORMALIZMA \\ Amund M. Rolfsen}

Formalna razmatranja predstavljaju srž aspekta rada Piter Ajzenmana (Peter Eisenman). Može se tvrditi da su ona jedina dosledna tema njegovog rada, i zasnivaju se na konceptu da je arhitektura posredovanje izmedju otelovljenog unutrašnjeg sveta ljudskih bića i spoljnog fizičkog sveta koji naseljavamo. Ajzenman tako daje „konceptualnu“, a ne percepcijsku osnovu, pri čemu su univerzalni formalni odnosi važniji od čulnih aspekata. Na taj način arhitektura ostaje kao 
sintaktička radnja zasnovana na razumu i logici, s očiglednim formalnim odnosima kao glavnim opravdanjem. Razumevanje i razvoj inherentnog formalnog jezika postaje glavni cilj takvog pristupa, a značenje se zanemaruje u svom spoljašnjem karakteru s pozivanjima na društvene, istorijske ili druge reprezentativne osobine.

U ovom radu raspravlja se o Ajzenmanovim pogledima na arhitektonski formalizam kroz sferu estetike. Budući da je tokom karijere zanemario estetska razmatranja, posebno lepotu, korisno je istražiti i ispitati njegov stav o svojstvima arhitekture kao načinu da opravda svoje tvrdnje o prednosti formalnosti. Data analiza zasniva se na formalističkim teorijama Nika Zangvila (Nick Zangwill) i na taj način prednost je data formalno-prostornim svojstvima arhitektonskog objekta onako kako o njima sudi osoba. To bi moglo da vrati rasprave o formalističkoj estetici u arhitektonsku teoriju i da donošenje suda o kvalitetu arhitekture bude formalno pitanje.

KLJUČNE REČI: ESTETSKA SVOJSTVA, FORMALIZAM, PITER AJZENMAN, UNUTRAŠNJA I SPOLJNA SVOJSTVA, NIK ZANGVIL

\section{SMRT ESTETIKE U ARHITEKTONSKOM OBRAZOVANJU? \\ MOGUĆNOSTI SAVREMENE PEDAGOGIJE}

\section{Renata Jadrešin Milić, Catherine Mitchell}

Značaj estetike u arhitekturi ima dugu istoriju. Iako pojam nije bio prisutan u pisanim traktatima pre 1735. godine i Baumgartena (Alexander Gottlieb Baumgarten), mesto estetike se može prepoznati kroz arhitektonsku teoriju i filozofiju još od vremena Vitruvija. Razvijanje estetskog senzibiliteta smatrano je ključnim za arhitektu, a proučavanje arhitekture shvaćeno je kroz tri Vitruvijeva koncepta (utlitas, firmitas, venustas) od kojih je venustas direktno povezan sa estetikom. Ovaj rad je odgovor na aktuelne diskusije izmedju arhitekata, arhitektonskih pedagoga i studenata arhitekture o ulozi estetike u arhitektonskom obrazovanju i stručnoj praksi danas. Prvobitno je inspirisan pitanjima postavljenim na godišnjim konferencijama SAH u 2017. i 2018. godini, o ulozi arhitektonske istorije u arhitektonskom projektovanju i praksi danas, a u vezi sa tim, i pitanjima o mestu estetike u arhitektonskom obrazovanju. Ovaj rad daje detaljan pregled ključnih pedagoških intervencija napravljenih u jednom programu studija arhitekture, koje mogu biti od koristi edukatorima zainteresovanim da održe mesto estetike u savremenom arhitektonskom obrazovanju. To sugeriše da estetika može i dalje da ima ključnu ulogu u arhitektonskom kurikulumu, fokusirajući sa na rešavanje projektantskih problema i istovremeno odgovarajući na savremene obrazovne zahteve za akreditaciju.

KLJUČNE REČI: ESTETIKA, ARHITEKTONSKO OBRAZOVANJE, BUDUĆE VEŠTINE ZA ZAPOŠLJAVANJE, KRITERIJUMI ZA AKREDITACIJU 